\title{
PRODUCTIVE AND REPRODUCTIVE EFFICIENCY OF RED CHITTAGONG CATTLE UNDER FARM CONDITION
}

\author{
M. P. Mostari, K. S. Huque ${ }^{1}$, M. S. Hasanat ${ }^{2}$ and Z. Gulshan ${ }^{3}$ \\ Bangladesh Livestock Research Institute, Savar, Dhaka-1341, Bangladesh
}

\begin{abstract}
The productive and reproductive efficiency of Red Chittagong cattle (RCC) reared at the Bangladesh Livestock Research Institute (BLRI) farm was evaluated. A total of $46 \mathrm{RCC}$ of different categories were considered under this study. Parameters studied were birth weight, weight at 3, 6 months of age and adult body weight, growth rate, daily milk yield, lactation length, lactation yield, age at puberty, weight at puberty, age at first calving, post partum estrus period, service per conception, calving interval and gestation length of RCC were collected and recorded. The birth weight differed significantly $(p<0.01)$ between male and female and the average birth weight of RCC calves at farm level was $14.87 \mathrm{~kg}$. The growth rates and adult body weight also differed significantly $(\mathrm{p}<0.05$ and $\mathrm{p}<0.01)$ between male and female except in growth rate from 3 to 6 months of age. The average daily milk yield, milk yield per lactation and lactation length of RCC were $2.24 \mathrm{~kg}$, $526.81 \mathrm{~kg}$ and 238 days, respectively. The age at puberty, service per conception, post partum estrus period and calving interval of RCC heifers and cows were 15 months, 1.15, 40 days and 11 months, respectively. It can be concluded that the RCC is a genetically and economically superior variety of Bangladesh.
\end{abstract}

Key Words : Red Chittagong cattle, Productive, Reproductive, Performance

\section{INTRODUCTION}

Red Chittagong Cattle (RCC), the designated title of the cattle originates from their typical red coat color and the title of the habitat. Chittagong, an administrative division and the district of the country, covers the southeastern hilly and coastal areas and a part of the eastern plain land. The RCC is sparsely distributed throughout these areas, but it is found in a higher concentration in the plain land of Chittagong district. The Red Chittagong cattle are not internationally considered as a pure breed, but as a variety (Mason, 1982). The RCC are found to have some of the productive and reproductive traits more economic than any other native, or even some exotic breeds. The most important factor that the animals are highly resistant to diseases especially under rural production systems, require lower input support than others and produce milk and beef of high quality. Another most economic character of the animal is higher live weight of males. This gives an opportunity of rearing them for fattening for beef meat production.

\footnotetext{
${ }^{1}$ Bangladesh Livestock Research Institute (BLRI), Savar, Dhaka, Bangladesh

2 City Industry Ltd., Dhaka, Bangladesh

${ }^{3}$ Department Biotechnology \& Genetics Discipline, Khulna University, Khulna, Bangladesh
} 
Khan et al. (1999) reported that the RCC attains sexual maturity early and calves regularly than non-descriptive Deshi. Although RCC cows produce low amount of milk but it contains a higher percentage of fat, about $6 \%$ (Akhter et al., 2004). Productive and reproductive efficiency of a cow are very important economic traits, which directly affect the profitability of a farm. These traits are also important indicators to select superior animals for breeding purpose. Very limited works have been done on RCC in terms of individual performance at farm condition (Habib, 2001; Akhter et al., 2004). Therefore, the present study was undertaken with the objectives to evaluate the productive and reproductive efficiency of RCC at farm condition.

\section{MATERIALS AND METHODS}

The present study was carried out at the research station of Bangladesh Livestock Research Institute (BLRI), Savar, Dhaka. The non-orthogonal information accumulated over a period of 2002 to 2005 of an individual since establishment of the farm were used as experimental materials of the present study. The conservation and development program of RCC in BLRI was started with 12 cows, 12 calves and 3 bulls, which were procured from Anawara and Chandanish upazilla of Chittagong district. A selective breeding plan for the improvement of RCC was started from August 2002, and it was designed in a way to avoid inbreeding effects. A mating plan was strictly followed in the research farm keeping the bulls under confinement. Under this program a selected stock is already been developed comprising 10 milking cows, 5 dry cows, 11 yearling bulls and heifers, 12 calves and 8 bulls. The animals other than the bulls are reared in semiintensive system. The cattle are allowed to graze on natural pasture from $9 \mathrm{~A}$. M. to 1.30 P. M. Straws or silage is provided during the draught period. A concentrate mixture is provided twice daily $(8 \mathrm{~A}$. M. and $4 \mathrm{P}$. M.) on the basis of live weight at the rate of 1 $\mathrm{kg} / 100 \mathrm{~kg}$ body weight. Data on birth weight, live weight of animals at 3 month, 6 month or at adult age, growth rate, daily milk yield, lactation yield, lactation length, age at puberty, weight at puberty, age at first calving, post partum estrus period, service per conception, calving interval and gestation length were recorded and expressed in kilogram $(\mathrm{kg})$, gram $(\mathrm{g})$, days $(\mathrm{d})$ and months $(\mathrm{m})$. The productive and reproductive indices used in discussion were measured in the following ways :

\begin{tabular}{ll}
\hline \multicolumn{1}{c}{ Traits } & \multicolumn{1}{c}{ Definition } \\
\hline Birth weight & Live weight of calves recorded within 24 hours of birth \\
Growth rate & Weight gain per day \\
Lactation length & Interval between first and last milking of a cow in the same lactation \\
Lactation milk yield & Quantity of milk given by a cow over a lactation period \\
Daily milk yield & Lactation milk yield divided by lactation length \\
Age at puberty & Age at which heifer allowed for first service \\
Weight at puberty & Weight at which heifer allowed for first service \\
Age at first calving & Age at which heifer gave first calf \\
Service per conception & Average number of services required for each successful conception \\
Post partum estrus & Interval between date of a given calving and the date of first \\
period & insemination after parturition \\
Gestation length & Days between effective insemination to concerned calving \\
Calving interval & Days between two successive calving \\
\hline
\end{tabular}


Effects of sex on different productive and reproductive performances were determined by student's t-test using SPSSx statistical computer package.

\section{RESULTS AND DISCUSSION}

\section{Body weight and growth rate}

The body weight and growth rate of Red Chittagong cattle at different ages are shown in Table 1 . In the present study body weight and daily gain at different ages differ significantly $(\mathrm{p}<0.01$ and $\mathrm{p}<0.05)$ between male and female except the daily gain during 3 to 6 months of age. Males are heavier than the females at all ages from birth to adult. Similar observations were reported by many other researchers (Habib, 2001; Jalil et al., 2002 and Gaur et al., 2003). The RCC male calves at birth $(16.31 \mathrm{~kg})$ are heavier than their opposite sex $(13.08 \mathrm{~kg})$. The average birth weight of the present study $(14.87 \mathrm{~kg})$ was lower than the same animal $(16.70 \mathrm{~kg})$ reared under confinement in Bangladesh Agricultural University (Habib, 2001). Gaur et al. (2003) reported higher body weights of Indian Gir cattle under its breeding tracts than that of the present study. They found 56.1 $\mathrm{kg}$ for male and $52.4 \mathrm{~kg}$ for female at 3 months and $87.7 \mathrm{~kg}$ and $83.9 \mathrm{~kg}$, respectively at 6 months of age. Higher adult body weight of Pabna cattle under farm condition was 475 $\mathrm{kg}$ for male and $280 \mathrm{~kg}$ for female (Jalil et al., 2002). This may be due to genetic variation. But the extent of differences in weight of RCC between male and female is higher than that of the others. This difference may be considered as an economic genetic trait of RCC for meat production or draught power from the male and low input based milk from the female.

Table 1. Body weight characteristics of Red Chittagong Cattle

\begin{tabular}{l|c|c|c|c}
\hline \multirow{2}{*}{ Parameter } & \multicolumn{3}{c|}{ Value (Mean \pm SE) } & $\begin{array}{c}\text { Level of } \\
\text { significance }\end{array}$ \\
\cline { 2 - 4 } & Male & Female & Overall & $* *$ \\
\hline Birth weight (kg) & $16.31 \pm 0.70(15)$ & $13.08 \pm 14(12)$ & $14.87 \pm 0.50(27)$ & $*$ \\
3 Month weight (kg) & $41.46 \pm 3.51(6)$ & $25.26 \pm 1.10(5)$ & $34.10 \pm 3.17(11)$ & $*$ \\
6 month weight (kg) & $66.90 \pm 3.08(10)$ & $52.50 \pm 2.02(7)$ & $60.97 \pm 2.63(17)$ & $*$ \\
Adult weight (kg) & $436.00 \pm 38.65(3)$ & $191.50 \pm 11.49(9)$ & $252.62 \pm 34.04(12)$ & $*$ \\
$\begin{array}{l}\text { Daily weight gain from } \\
\text { birth to 3 month (g) }\end{array}$ & $271.48 \pm 35.40(6)$ & $132.88 \pm 11.035)$ & $208.48 \pm 28.98(11)$ & $*$ \\
$\begin{array}{l}\text { Daily weight gain from } \\
\text { birth to 6 month (g) }\end{array}$ & $277.72 \pm 15.54(10)$ & $220.63 \pm 10.87(7)$ & $254.21 \pm 12.14(17)$ & $*$ \\
$\begin{array}{l}\text { Daily weight gain from 3 } \\
\text { to 6 month (g) }\end{array}$ & $350.55 \pm 34.35(4)$ & $312.96 \pm 12.96(3)$ & $334.44 \pm 20.46(7)$ & NS \\
\hline
\end{tabular}

Figures in the parenthesis indicate the total number of observations; ${ }^{*}=$ Significant at $5 \%$ level; ** $=$ Significant at $1 \%$ level; NS = Non significant

The daily gain of RCC is higher in 3 to 6 months of age compare to that in birth to 3 months or the average of birth to 6 months of age. Habib (2001) reported the average growth rate of RCC female calves as $190 \mathrm{~g}$ per day, which is close to the average growth 
rate found during birth to 6 months of age of RCC female calves of the present study. Hossain and Routledge (1982) studied growth rate performances of Pabna and Deshi calves and found 178 and $168 \mathrm{~g}$ per day, respectively which were lower than the present study.

\section{Milk yield and lactation length}

Average lactation yield, lactation length and daily milk yield of RCC cows are shown in Table 2. The overall lactation length was 237 days (d). The highest lactation length was 249 days in $1^{\text {st }}$ lactation followed by 213 days in the $2^{\text {nd }}$ lactation. The lactation length was significantly ( $\mathrm{p}>0.05)$ affected by parity or different lactations. Khan et al. (2000) studied lactation length of RCC and found 222.85 days under farm condition which was slightly lower than that of the present study. Ahmed and Islam (1987) summarized the performance of local cattle for lactation length and found an average of $270 \mathrm{~d}$, which was higher than that of the present study.

Table 2. Milk yield and lactation length of Red Chittagong Cattle

\begin{tabular}{l|c|c|c|c}
\hline \multirow{2}{*}{ Parameter } & \multicolumn{3}{c|}{ Value (Mean \pm SE) } & Level of \\
& Fignificance \\
\cline { 2 - 4 } & First lactation & Second lactation & Overall & $*$ \\
\hline Lactation length (d) & $249.60 \pm 8.14(10)$ & $213.60 \pm 12.86(5)$ & $237.60 \pm 8.04(15)$ & NS \\
Lactation milk yield (kg) & $511.42 \pm 39.84(10)$ & $557.60 \pm 39.09(5)$ & $526.81 \pm 29.32(15)$ & - \\
Daily milk yield (kg) & - & - & $2.24 \pm 0.12(15)$ & - \\
\hline
\end{tabular}

Figures in the parenthesis indicate the total number of observations

The highest lactation yield was found in 2nd lactation $(577.60 \mathrm{~kg})$ followed by in Ist lactation $(511.42 \mathrm{~kg})$. The overall lactation milk yield was $526.81 \mathrm{~kg}$. The effect of lactation on lactation yield was insignificant ( $p>0.05$ ). Hossain and Routledge (1982) reported that lactation yield of local cows was $213.0 \mathrm{~kg}$ under village condition which was lower than that of the present study. The average daily milk yield of RCC was $2.24 \mathrm{~kg}$, which is close agreement with Habib (2001) who found $2.55 \mathrm{~kg}$ milk per day. The average daily milk yield curve of RCC is shown in Fig. 1. Khan et al. (2000) studied milk yield/d of RCC under farm and rural conditions and found 2.0 and $1.80 \mathrm{~kg}$ respectively, which are lower than that of the present finding. Bhuiyan and Faruque (1993) analyzed daily milk yield of 340 local cows and found to be $1.63 \mathrm{~kg}$. This result was also lower than that of the present findings. Jabbar and Ali (1985) studied daily milk production performance of local cows, which averaged $2.42 \mathrm{~kg}$. This result had a similarity to the present finding.

\section{Reproductive performances}

Reproductive performances of RCC are presented in Table 3. The age at puberty of RCC was 15.29 months $(\mathrm{m})$ which was about $17 \mathrm{~m}$ lower than local cows $(32.0 \mathrm{~m})$ reported by Majid et al.(1998) and about $19.0 \mathrm{~m}$ lower than the Pabna cows $(34.4 \mathrm{~m})$ reported by Jalil et al. (2002). The average service per conception of RCC was 1.15 which was close agreement with the study of Habib (2001) who found 1.25 service per conception for RCC but Khan et al. (1999) studied the performances of RCC and Pabna cattle and reported 
that service per conception were 1.61 and 1.57 , respectively which were higher than that of the present study. A number of factors which might have influenced for the variation of service per conception such as the quality and quantity of semen, improper detection of heat, failure to inseminate at appropriate time, the level of fertility which might be influenced by the age of bull and cow, season of the year, diseases and other environmental factors. The post partum oestrus period of RCC was only $40.11 \mathrm{~d}$. This result reveals that the RCC after parturition comes into heat $163 \mathrm{~d}$ earlier than the local cows (202.7 d) reported by Majid et al. (1998).

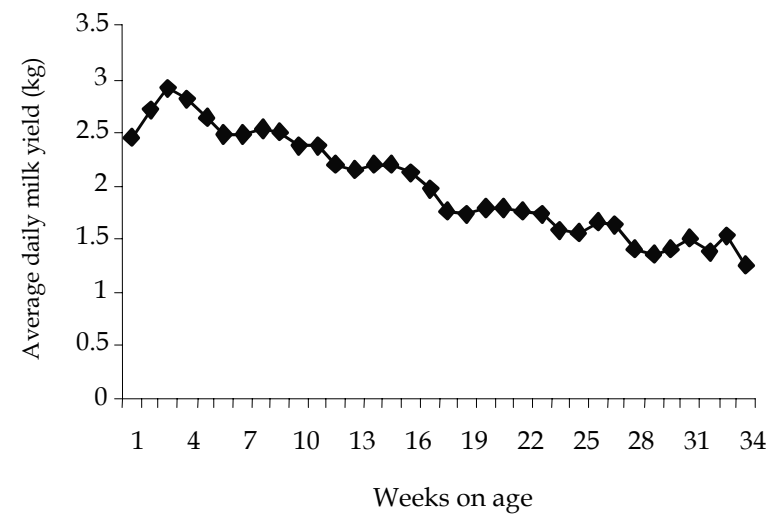

Fig. 1. Lactation curve of RCC cows

Table 3. Reproductive performances of RCC

\begin{tabular}{lcc}
\hline \multicolumn{1}{c|}{ Parameters } & Observation & Mean \pm SE \\
\hline Age at puberty $(\mathrm{m})$ & 3 & $15.29 \pm 0.48$ \\
Weight at puberty $(\mathrm{kg})$ & 3 & $133.16 \pm 1.69$ \\
Age at first calving (m) & 3 & $24.65 \pm 0.68$ \\
Service per conception (No.) & 20 & $1.15 \pm 0.08$ \\
Post partum estrus period (d) & 9 & $40.11 \pm 5.37$ \\
Gestation length (d) & 21 & $285.80 \pm 1.38$ \\
Calving interval (m) & 11 & $11.21 \pm 0.30$ \\
\hline
\end{tabular}

The gestation length is a species characteristic. The variation of gestation length is genetically determined. Variation may be due to maternal influence. A little variation in gestation length within the individual may be contributed mainly by maternal and fetal factors. Ages of dam, nutritional body condition of the dam are the maternal factors. On the other hand, fetal factor include the sex of the fetus, twining and hormonal functions of the fetus. Environmental factors such as season, temperature, feeding and management may also contribute to some extent. The average interval between two successive calving of RCC was $11.21 \mathrm{~m}$ which was lower than that of Pabna cows (14.87 $\mathrm{m})$ reported by Jalil et al. (2002). 
The herd size is too small to draw any conclusion on dairy characters of cows or growth performance of males. However, the age at puberty, the service per conception and post partum oestrus period of RCC are very low compare to others. On the other hand, the extent of difference in growth rate of RCC male and female are higher than that of the other breeds.

\section{REFERENCES}

Ahmed, Z., and Islam, T. S. 1987. Cattle breeding program through Artificial Insemination in Bangladesh. A. I. Extension Project Report, CCBS, Dhaka.

Akhter, S., Huque, K. S., Jalil, M. A., and Islam, M. R. 2004. Conservation, selection and improvement of Red Chittagong Cattle through selective breeding, feeding and management. Annual Research Review workshop on 10-11 June, held in Bangladesh Livestock Research Institute, Savar, Dhaka.

Bhuiyan, A. K. F. H. and Faruque, M. O. 1993. Yield and variability of milk production in the local cattle of Bangladesh. Proceeding of the BAURES Workshop.

Gaur, G. K., Kaushik, S. N., and Garg, R. C. 2003. The Gir cattle of India- characteristics and present status. Animal Genetic Resources Information. 33 : 21-29.

Habib, A. 2001. Study on the Red Chittagong cattle-an animal genetic resource of Bangladesh. M S thesis. Dept. of Animal Breeding and Genetics. BAU, Mymensingh.

Hossain, M. A. and Routledge, S. F. 1982. Performance of crossbred and local cattle under village conditions in Pabna district of Bangladesh. Proceeding of maximum livestock production from minimum land. Seminar Paper, p. 161-167.

Jabbar, M. A. and Ali, S. Z. 1985. The limitations of crossbreeding for improvement of cattle in Bangladesh. Oxford Agrarian Studies. 19.

Jalil, M. A., Huque, K. S., Islam, M. R., Akhter, S., and Miah, G. 2002. Development of dairy breed from Pabna cattle. Annual Research Review Workshop on 25-26 th June, held in Bangladesh Livestock Research Institute, Savar, Dhaka.

Khan, A. A., Ali, A., Husain, S. S. and Bhuiyan, A. K. F. H. 1999. Reproductive performances of different genetic group of cows under farm condition. Bangladesh J. Anim. Sci., 28(1-2) : 59-64

Khan, M. K. I., Huque, K. S., Miah, A. G. and M. J. 2000. Study on the performance of Red Chittagong cows under different production system. Pakistan J. Bio. Sci., 3(2) : 318-319.

Majid, M. A., Nahar, T. N., Hossain, K. M. and Talukder, A. I. 1998. Investigation on the strategy and impact of artificial insemination programme and performance of crossbred cattle in Bangladesh. A Report. Submitted to Animal Production Research Division. BLRI. Savar, Dhaka.

Mason, J. L. and Buvanendran, V. 1982. Breeding plans for ruminant livestock in the tropics. FAO Animal Production and Health Paper. p. 34-89. 